\title{
A "Revista da Faculdade de Direito" Agradece Colaboração de Ex.Aluno
}

\section{A Redação}

A Revista da Faculdade de Direito, através de sua D.D. Comissão de Redação, consigna neste volume especial reconhecimento por espontânea, graciosa e anônima colaboração prestada durante 25 anos pelo bacharel GERALDO TOLOSA.

GERALDo Tolosa, ex-aluno desta Faculdade, foi quem verteu os índices da "Revista da Faculdade de Direito" para o francês e inglês, desde o volume 51-1956 até este mesmo número 76-1981, tendo contribuído dessa forma para a divulgação da Revista nos países estrangeiros.

Registre-se que em sua liberalidade e amor à antiga escola, visou apenas colaborar para que a doutrina jurídica dos Professores de sua Faculdade fosse, em síntese, entendida no exterior. $\mathrm{E}$, a título de contribuição para as memórias acadêmicas, lembre-se, também, que nosso colaborador de tantos anos lecionou francês e inglês, desde 1944 no Curso Castelões, tendo preparado para concursos vestibulares ao Direito 4.872 alunos, dos quais 3.100, aproximadamente, foram aprovados nesta Faculdade.

Portanto, a "Revista da Faculdade de Direito" da Universidade de São Paulo faz justiça, expressando aqui sua gratidão. 